\section{Cost Benefit Analysis of Using Grafted Transplants for Root-knot Nematode Management in Organic Heirloom Tomato Production}

\author{
Charles E. Barrett ${ }^{1,3}$, Xin Zhao ${ }^{1,4,6}$, and Alan W. Hodges ${ }^{2,5}$
}

\begin{abstract}
AdDITIONAL INDEX wORDs. sensitivity analysis, partial budget analysis, Meloidogyne sp., Solanum lycopersicum $\times$ S. habrochaites, rootstock, scion

SUMMARY. Growers are looking for sustainable alternatives to methyl bromide as a soil fumigant that are effective and economical. Increased demand for organically produced fruits and vegetables has also contributed to the need for environmentally friendly soil-borne disease control methods. Grafting may be a valuable tool for vegetable growers to cope with pest management challenges in production of cucurbits and solanaceous crops; however, there are concerns regarding the higher costs associated with the use of grafted plants in the United States. The main objective of this 2-year study was to determine if grafting with a resistant rootstock could be cost-effective to overcome root-knot nematodes (RKN) (Meloidogyne sp.) and maintain fruit yield in organic heirloom tomato (Solanum lycopersicum) production in Florida's sandy soils. The heirloom tomato cultivar Brandywine was grafted onto the rootstock 'Multifort'. Nongrafted and grafted 'Brandywine' plants were grown organically in two fields that exhibited different levels of RKN infestations. Grafted and nongrafted transplants were estimated to cost $\$ 0.78$ and $\$ 0.17$ per plant, respectively. The cost of rootstock seeds accounted for $36 \%$ (\$0.28/plant) of the total cost of the grafted transplants and $46 \%$ of the cost difference between grafted and nongrafted plants. Sensitivity analyses were conducted using these estimated transplant production costs and crop yield data from the field trials as well as price information for heirloom tomato. Results showed that under severe RKN pressure, grafting may be an economically feasible pest control measure to help maintain a profitable production given that the risk of economic crop losses due to RKN outweighed the higher cost of grafted transplants.
\end{abstract}

$\mathrm{V}$ egetable grafting is popular in Asian and European countries where continuous cropping and intensive production is practiced. This technique offers resistance/tolerance to biotic and abiotic stressors in a variety of cucurbitaceous and solanaceous crops (Kubota et al., 2008; Lee et al., 2010; López-Pérez et al., 2006; Louws et al., 2010; Rivard et al., 2010a; Venema et al., 2008). In the United States, vegetable grafting is gaining in importance because of the phase out of soil fumigation with methyl bromide

\footnotetext{
We would like to thank Southern Region Sustainable Agriculture Research and Education (SARE) for the Graduate Student Grant awarded to Charles Barrett.

We also thank Dr. Robert McSorley and Dr. Charles Sims for their research advice and help in preparation of this manuscript.

${ }^{1}$ Horticultural Sciences Department, University of Florida, Gainesville, FL 32611-0690

${ }^{2}$ Food and Resource Economics Department, University of Florida, Gainesville, FL 3261 1-0240

${ }^{3}$ Graduate Research Assistant

${ }^{4}$ Assistant Professor

${ }^{5}$ Extension Scientist

${ }^{6}$ Corresponding author. E-mail: zxin@ufl.edu.
}

(King et al., 2008). Since the price of methyl bromide is increasing and the price of grafted plants is decreasing, vegetable grafting may be an economically viable method of disease control in the United States.

The continued increase in demand for foods produced organically (Greene et al., 2009) may also have helped fuel the interest in vegetable grafting in the United States. For instance, organic growers have used grafting to control RKN (Kubota et al., 2008), which are a major problem in the sandy soils common to Florida (Roberts et al., 2005). RKN-resistant tomato rootstocks have been shown to reduce RKN galling and maintain yields
(Bausher, 2009; Louws et al., 2010; Rivard et al., 2010b; Verdejo-Lucas and Sorribas, 2008). However, grafting in the United States has not yet reached its full potential as a control for soilborne pathogens and nematodes.

It has been estimated that 40 million grafted vegetable transplants are currently used in the United States every year. Most of these plants are produced in Canada and are used by major greenhouse tomato producers for season extension and increased crop vigor (Kubota et al., 2008). In contrast, over 200 million grafted tomato transplants are used annually in Japan and Korea for improved crop production and relief from soil-borne pathogens, temperature extremes, and soil salinity (Lee et al., 2010). Grafting in the United States is expected to expand greatly in the coming years as more uses are realized, high-quality transplants become more available, and prices for grafted transplants are reduced (King et al., 2008; Kubota, 2008; Lee et al., 2010).

High labor costs and low return per plant have been suggested as barriers to adoption of grafted vegetable production in the United States. (Rivard et al., 2010b). Lee et al. (2010) reported prices of grafted transplants between $\$ 0.40$ and $\$ 1.20$ for various crops. Grafted tomato transplants can cost between $\$ 0.60$ and $\$ 0.90$ per plant without factoring in seed costs (Kubota et al., 2008). Although interest in this technique is on the rise, there has been little reported on the price of grafted transplants for vegetable production in the United States. Prices for domestic grafted tomato plants were estimated by Rivard et al. (2010b) at $\$ 0.59$ (on-farm, organic) and $\$ 1.88$ (retail, double-stem pruned for greenhouse production) as compared with $\$ 0.13$ (on-farm, organic) and $\$ 0.76$ (retail, double-stem pruned for greenhouse production) for nongrafted plants in two different transplant production facilities. However, to our knowledge, there have been few

\begin{tabular}{llll}
\hline $\begin{array}{l}\text { Units } \\
\text { To convert U.S. to SI, } \\
\text { multiply by }\end{array}$ & U.S. unit & SI unit & $\begin{array}{l}\text { To convert SI to U.S., } \\
\text { multiply by }\end{array}$ \\
\hline 3.7854 & gal & $\mathrm{L}$ & 0.2642 \\
2.54 & inch(es) & $\mathrm{cm}$ & 0.3937 \\
25.4 & inch $(\mathrm{es})$ & $\mathrm{mm}$ & 0.0394 \\
0.4536 & $\mathrm{lb}$ & $\mathrm{kg}$ & 2.2046 \\
0.9464 & $\mathrm{qt}$ & $\mathrm{L}$ & 1.0567 \\
$\left({ }^{\circ} \mathrm{F}-32\right) \div 1.8$ & ${ }^{\circ} \mathrm{F}$ & ${ }^{\circ} \mathrm{C}$ & $\left(1.8 \times{ }^{\circ} \mathrm{C}\right)+32$
\end{tabular}


studies examining both the cost of grafted tomato transplants and their expected return. This information could help growers decide if the extra cost of grafted transplants could be justified by increased output or by the reduction of production inputs when using grafting to overcome soil-borne diseases.

Florida growers and transplant producers interested in vegetable grafting need information based on local production systems. The purpose of this study was to determine the cost of producing grafted heirloom tomato transplants on-farm and estimate the economic return with expected yields for organic growers interested in implementing this technique. Sensitivity analyses were performed to assess the economic feasibility of growing grafted heirloom tomato plants. These analyses were developed using fruit yield information from field trials of heirloom tomato grown under different levels of RKN infestations.

\section{Materials and methods}

Transplant production. Certified organic scion seeds and untreated rootstock seeds were used to produce transplants in accordance to the rules outlined by the National Organic Program [U.S. Department of Agriculture (USDA), 2002]. The heirloom tomato cultivar Brandywine [BW (Tomato Fest, Little River, CA)] was used for the scion and nongrafted transplants. BW is popular with local growers and consumers. The interspecific hybrid rootstock (S. lycopersicum $\times$ S. habrochaites) cultivar Multifort [MU (De Ruiter Seeds, Bergschenhoek, The Netherlands)] was used for the rootstock of the grafted transplants. MU was chosen for its vigor and resistance to soil-borne pathogens including $\mathrm{RKN}$.

To provide seedlings with similar stem diameter for grafting, rootstock seeds were sowed $2 \mathrm{~d}$ before sowing the scion seeds. Grafting occurred $34 \mathrm{~d}(2010)$ and $28 \mathrm{~d}(2011)$ after the scion seeds were sowed. Seedlings were splice grafted at the three- to fiveleaf stage. A 1.5- or 2.0-mm silicone grafting clip (Hydro-Gardens, CO Springs, CO) was used to hold the grafted scion and rootstock together. Grafted seedlings were placed in a climate controlled walk-in cooler at $25^{\circ} \mathrm{C}$ and $95 \%$ relative humidity and kept in darkness for $24 \mathrm{~h}$. Relative humidity was reduced and light exposure was increased for $6 \mathrm{~d}$ following grafting until the grafted transplants were healed. The transplants were then hardened off in the greenhouse for $3 \mathrm{~d}$ before transplanting into the field. Grafting and healing procedures were adapted from Rivard and Louws (2006). Nongrafted transplants were grown in the greenhouse until transplanting into the field. Transplanting took place on 10 Apr. 2010 and 2 Apr. 2011.

Field tRIALs. An organic field trial was conducted in 2010 and repeated in 2011. A transitional organic field trial was also conducted in 2011 at a site with a history of nematode infestation. This trial was designed to resemble a field in the 3 -year transition to organic. A randomized complete block design with five replications (blocks) was used for all three field trials. Each trial consisted of two treatments: nongrafted BW (NGBW) and $\mathrm{BW}$ grafted onto MU (BW/MU). All field trials were conducted at the University of Florida Plant Science Research and Education Unit in Citra, FL. The soil at the research site was classified as Candler sand, hyperthermic, uncoated Typic Quartzipsamments. Fruit were harvested at the breaker stage of ripeness. Tomato harvests for the organic fields took place on $7,13,17$, and 25 June 2010; and 4, 8, 13, 16, 22, and 28 June 2011. The transitional field was harvested on 4, 8, 13, 16, and 23 June 2011. All tomatoes were graded as if they were to be sold. Tomato marketability was based on experience gained from meeting with local heirloom tomato growers. Fruit that were not marketable were culled according to their defect (e.g., blossom end rot, catfacing, splitting, etc.). After grading, all fruit were counted and weighed. At the completion of each trial, roots of five plants per treatment in each block in the organic fields and three plants per treatment in each block in the transitional field were assessed for nematode galls. In both years, the root gall rating scheme proposed by Zeck (1971) was used to estimate nematode infestation levels on plant root systems. This scale is organized from 0 to 10 , where $0=$ no galling and $10=$ plant and roots are dead. Three researchers assessed each plant individually and then the ratings were averaged for each plant. The plant ratings were then averaged for each treatment in each block (five plants per plot in the organic fields; three plants per plot in the transitional field).

Economic analyses. Sources and prices for materials and labor used to perform the partial budget analysis were identified for estimating the cost of producing grafted heirloom tomato transplants (Table 1). A partial budget analysis can be used to examine the effects of changes in costs of certain production inputs on the change of profit of a farming operation. This technique focuses on the portion of the budget of interest rather than an entire budget. A partial budget analysis was conducted using data acquired during this grafted heirloom tomato study. All phases of grafted and nongrafted transplant production were recorded to provide accurate estimates for labor, materials, and total transplant production costs. Production costs were based on a target of 1000 grafted and nongrafted transplants. The 2011 average wage for an entry-level agricultural worker in the state of Florida was $\$ 8.45 / \mathrm{h}$ (Florida Department of Economic Opportunity, 2011). This wage was used for all labor calculations. The cost of BW seed for the nongrafted transplants reflected the over-seeded rate of $10 \%$ to account for $90 \%$ germination. Scion and rootstock seed costs for the grafted transplants reflected the over-seeded rate of $25 \%$ to account for $90 \%$ germination and $90 \%$ grafting success. The cost of one grafted vs. nongrafted transplant was then calculated from the total cost of production for 1000 transplants.

Costs for constructing a simple healing chamber were based on experience gained at the University of Florida and reflected a practical option for small growers and grafters. Although a walk-in cooler was used in this study for healing the grafted transplants, a simpler structure may be conveniently substituted.

Sensitivity analyses were conducted to compare partial net returns for grafted and nongrafted plants grown under organic and transitional to organic growing conditions. These partial net returns per plant were calculated by subtracting the cost of the transplant from the estimated return and do not account for other production costs (e.g., transplanting labor, field preparation, mulch, fertilizer, etc.). Sensitivity analyses were carried out using the mean yield per plant $\pm 3 \mathrm{SE}$ 
Table 1. Sources and prices for materials used to produce grafted and nongrafted heirloom tomato transplants.

\begin{tabular}{|c|c|c|c|c|c|}
\hline Item & Description & $\mathrm{Unit}^{\mathrm{z}}$ & $\begin{array}{c}\text { Price } \\
(\$ / \text { unit })^{\mathrm{y}}\end{array}$ & $\begin{array}{l}\text { Lifespan } \\
\left(^{(y e a r s)^{x}}\right.\end{array}$ & Source \\
\hline \multicolumn{6}{|l|}{ Seedling materials } \\
\hline 'Multifort' & Rootstock & 250 seeds & 57.00 & & Paramount Seeds, Palm City, FL \\
\hline $\begin{array}{l}\text { Fafard custom } \\
\text { organic mix }\end{array}$ & Potting soil & 40 -qt bag & 9.50 & & BWI, Apopka, FL \\
\hline Neptune's harvest & $\begin{array}{l}\text { Liquid organic } \\
\text { fertilizer }\end{array}$ & $1 \mathrm{gal}$ & 45.50 & & $\begin{array}{c}\text { Neptune's Harvest, } \\
\text { Gloucester, MA }\end{array}$ \\
\hline \multicolumn{6}{|l|}{ Grafting supplies } \\
\hline $\begin{array}{l}2.0-\mathrm{mm}(0.079 \mathrm{inch}) \\
\text { clips }\end{array}$ & $\begin{array}{l}\text { Silicone grafting } \\
\text { clips }\end{array}$ & 1000 clips & 42.00 & & $\begin{array}{l}\text { Hydro-Gardens, CO Springs, } \\
\text { CO }\end{array}$ \\
\hline Cool-mist humidifier & Maintains humidity & Per chamber & 25.00 & 5 & $\begin{array}{l}\text { Local/regional department } \\
\text { store }\end{array}$ \\
\hline Air conditioner & Window unit & Per chamber & 159.00 & 5 & Local/regional hardware store \\
\hline $\begin{array}{l}\text { Wood, PVC pipe, plastic } \\
\text { sheeting, etc. }\end{array}$ & $\begin{array}{l}\text { Frame and covering } \\
\text { for chamber }\end{array}$ & Per chamber & 26.86 & 5 & Local/regional hardware store \\
\hline
\end{tabular}

${ }^{2} 1 \mathrm{qt}=0.9464 \mathrm{~L}, \mathrm{l}$ gal $=3.7854 \mathrm{~L}$.

'Based on Fall 2011 prices.

${ }^{x}$ Expected years of use, a straight-line depreciation was applied for the number of years indicated.

and a range of average price per pound received for organic heirloom tomato fruit. Mean yield per plant $\pm 3 \mathrm{SE}$ were used to provide a $99 \%$ confidence interval of expected yields. The mean yield per plant and SE for nongrafted and grafted plants were estimated from the analyses of yield data from the 2010 and 2011 field trials using the GLIMMIX procedure in SAS (version 9.2; SAS Institute, Cary, NC). The tomato yield data used to construct the grafted and nongrafted analyses for the organic field were pooled from 2010 and 2011 to form a more representative data set. The range of prices per pound used for the sensitivity analyses were derived from the monthly average price of a 10 -lb carton of organic heirloom tomato fruit, as published by the USDA from 2008 (USDA, 2009).

\section{Results and discussion}

Transplant cost analyses. Sources and prices for materials used in production of grafted and nongrafted heirloom tomato transplants are shown in Table 1. Grafted transplants required more materials, seeds, and labor and were more expensive to produce than nongrafted plants. In this study, grafted transplants cost $\$ 0.78$ per plant while nongrafted transplants cost $\$ 0.17$ per plant (Table $2)$. Our results were consistent with results reported by Rivard et al. (2010b) that estimated a cost of $\$ 0.59$ per grafted plant and $\$ 0.13$ per nongrafted plant for organically produced tomato transplants. The bulk of this price difference was associated with the price of the rootstock seeds, which accounted for 36\% (\$0.28) plant) of the total cost of the grafted transplants and $46 \%$ of the cost difference between grafted and nongrafted transplants. It has been suggested that high labor costs could be a major barrier to adoption of grafted vegetable production (Kubota et al., 2008; Rivard et al., 2010b); however, labor costs were not a major factor for grafted transplant cost, accounting for only $15 \%$ ( $\$ 0.09 /$ plant $)$ of the cost difference between grafted and nongrafted transplants.

Overall, grafting added $\$ 0.61$ per transplant to the cost of production. This is similar to the $\$ 0.60$ to $\$ 0.90$ (excluding seed cost) per grafted transplant price reported by Kubota et al. (2008). Our results were also consistent with the per transplant price increase of $\$ 0.46$ in North Carolina and \$0.74 in Pennsylvania for grafted tomato production as reported by Rivard et al. (2010b).
The cost of building an inexpensive but effective healing chamber was considered in the cost estimation of grafted transplants instead of the walkin cooler that was actually used since a walk-in cooler may not be available to some growers. However, it should be noted that using a walk-in cooler as a healing chamber might help reduce the cost of producing grafted transplants by achieving a high graft survival rate and avoiding the cost of building a healing chamber.

Lowering the cost of grafted transplants and rootstock seeds could increase adoption of the grafting technique by vegetable growers in the United States. The price reduction of grafted transplants may be more important for commercial producers who rely on propagators to supply large quantities of high-quality transplants. Decreasing the rootstock seed cost is the most important factor for decreasing the cost of grafted seedlings. In addition, improving the graft survival rate and efficiency of grafted transplant production will also help reduce the cost of grafted plants.

Sensitivity analyses. Sensitivity analyses are useful for systematically estimating changes in variables in an economic model. In the present study, we used sensitivity analyses to 
Table 2. Costs of grafted and nongrafted organic heirloom tomato transplants.

\begin{tabular}{|c|c|c|c|c|}
\hline \multirow[b]{3}{*}{ Item } & \multicolumn{2}{|c|}{ Grafted $^{\mathrm{z}}$} & \multicolumn{2}{|c|}{ Nongrafted ${ }^{\mathrm{y}}$} \\
\hline & Labor $^{x}$ & Material & Labor $^{x}$ & Material \\
\hline & \multicolumn{2}{|c|}{$(\$ / 1000 \text { plants })^{\mathrm{w}}$} & \multicolumn{2}{|c|}{$(\$ / 1000 \text { plants })^{\mathrm{w}}$} \\
\hline \multicolumn{5}{|l|}{ Seeds } \\
\hline Scion ('Brandywine') ${ }^{\mathrm{v}}$ & & 49.56 & & \multirow[t]{2}{*}{43.66} \\
\hline Rootstock ('Multifort') ${ }^{\mathrm{u}}$ & & 285.00 & & \\
\hline \multicolumn{5}{|l|}{ Seedling production } \\
\hline Potting soil & & 19.00 & \multirow{4}{*}{59.15} & 9.50 \\
\hline Flats $^{t}$ & & 27.76 & & 12.49 \\
\hline Seed sowing and care & 92.95 & & & \\
\hline Liquid fertilizer & & 91.00 & & 45.50 \\
\hline \multicolumn{5}{|l|}{ Grafted transplant production } \\
\hline Graftings & 52.81 & & & \\
\hline Silicone clips & \multicolumn{2}{|r|}{56.70} & & \\
\hline Miscellaneous supplies & \multirow{2}{*}{\multicolumn{2}{|c|}{21.13}} & & \\
\hline Post-graft care & & & & \\
\hline \multicolumn{5}{|l|}{ Healing chamber ${ }^{r}$} \\
\hline Humidifier & & 5.49 & & \\
\hline Air conditioner & & 31.80 & & \\
\hline Building supplies & & 26.86 & & \\
\hline Assembly & 16.90 & & & \\
\hline Subtotal & 183.79 & 601.17 & 59.15 & 111.15 \\
\hline Total & \multicolumn{2}{|c|}{784.96} & \multicolumn{2}{|c|}{170.30} \\
\hline Cost/plant & \multicolumn{2}{|c|}{0.78} & \multicolumn{2}{|c|}{0.17} \\
\hline \multicolumn{5}{|c|}{$\begin{array}{l}\text { "Seeds over sowed by } 25 \% \text { to account for } 90 \% \text { graft success and } 90 \% \text { germination. } \\
\text { ySeeds over sowed by } 10 \% \text { to account for } 90 \% \text { germination. } \\
\text { x } \$ 8.45 / \text { h pay wage for all labor. } \\
\text { "Estimate of costs based on Fall } 2011 \text { prices for a target } 1000 \text { grafted transplants. } \\
\text { "Indeterminate heirloom tomato cultivar, certified organic seed. } \\
\text { "Interspecific hybrid rootstock, untreated seed. } \\
\text { "1 } 128 \text {-cell count transplant flats, straight line depreciated for } 5 \text {-years estimated use. } \\
\text { s } 200 \text { plants/grafter per hour graft rate. }\end{array}$} \\
\hline
\end{tabular}

estimate the return per plant of grafted and nongrafted heirloom tomato production with varying yields and prices per pound of tomato fruit. Sensitivity analyses were developed to compare grafted transplant cost and economic returns associated with expected yields. Excluding the extra cost of grafted transplants, overall production costs would be similar whether grafted or nongrafted transplants were used assuming crop management practices were similar. Comparisons were made between plants grown in a field with relatively low RKN infestations and plants grown in a field with high RKN infestations to assess the economic feasibility of using grafted transplants for RKN control.

This study focused on organic heirloom tomato production because of the unique opportunity for vegetable grafting to be adopted by these typically smaller growers. Heirloom tomatoes often command a higher market price than regular fresh market tomatoes. Organic produce also commands a higher price at market. Therefore, organic heirloom tomatoes offer a niche market with price premiums that afford more opportunity for growers to experiment with grafted transplants. This is especially true when using grafted transplants with high resistance/tolerance to soil-borne diseases for yield improvement in fields with a history of severe infestation.

Root-knot nematode galling was not observed during the organic field trial conducted in 2010. There was root galling in the 2011 organic field trial, but the lower galling ratings for grafted plants did not result in increased yield as compared with nongrafted plants (data not shown). The 2010 and 2011 growing seasons were also very different with respect to climatic conditions. According to the data provided for Citra, FL, by the Florida Automated Weather Network, the Spring 2010 growing season (February-June) accumulated $167 \mathrm{~mm}$ more rainfall and there was an increased incidence of bacterial spot (caused by Xanthomonas campestris). Overall, the Spring 2011 season was a much more mild and dry growing season and was more favorable for growing a tomato crop. Yield data from the organic fields were pooled from the two seasons to provide a representative estimate for an average year in the present study. The performance of $\mathrm{BW}$ as a low-yielding heirloom tomato cultivar from this study was comparable to that reported previously (Kline and Nitzsche, 2005; Williams et al., 2005). However, little information is available from the literature with respect to yield of BW tomato grown organically. Relatively low marketable yield of field-grown organic heirloom tomato during the spring season in FL conditions may be expected given the short growing period and high pest pressure.

The results of the sensitivity analyses presented in Table 3 were representative of expected yields for grafted and nongrafted heirloom tomato plants grown in an organic field with relatively low RKN pressure. NGBW plants produced a mean marketable yield of $1.8 \mathrm{lb}$ per plant, and at that yield for the lowest tomato price per pound $(\$ 1.80 / \mathrm{lb})$, the estimated partial net return was $\$ 3.07 /$ plant. This was $\$ 1.49$ more than the estimated partial net return for the mean marketable yield of $\mathrm{BW} / \mathrm{MU}$ at $1.31 \mathrm{lb}$ per plant at the same price of $\$ 1.80 / \mathrm{lb}$. This comparison demonstrates that grafting may not be economically feasible when applied to fields with low RKN pressure and insignificant yield improvement as a result of grafting. Taylor et al. (2008) came to a similar conclusion that farmers growing seedless watermelon (Citrullus lanatus) should not consider using grafted plants if Fusarium wilt (caused by Fusarium oxysporum) is not an issue.

Table 4 shows the sensitivity analysis results based on expected yields for nongrafted and grafted plants grown in a research plot representing a field under transition to organic with high RKN pressure. The NGBW plants in this transitional field trial had a mean marketable yield of $0.35 \mathrm{lb}$ per plant with an expected partial net return of $\$ 0.46 /$ plant at $\$ 1.80 / \mathrm{lb}$ of heirloom tomato fruit. The mean marketable yield of BW/MU plants was $1.44 \mathrm{lb}$ per plant, which was $311.4 \%$ higher than that of NGBW. The expected partial net return per plant for BW/ MU was $\$ 1.81$ at $\$ 1.80 / \mathrm{lb}$. This represents a $\$ 1.35 /$ plant difference 
Table 3. Estimated partial net return per plant for plants of nongrafted 'Brandywine' tomato and 'Brandywine' grafted onto the rootstock 'Multifort' grown organically with low root-knot nematode pressure.

\begin{tabular}{|c|c|c|c|c|c|c|c|c|c|}
\hline \multirow[b]{3}{*}{ SE } & \multirow{3}{*}{$\begin{array}{c}\text { Yield } \\
(1 \mathrm{~b} / \text { plant })^{\mathrm{z}}\end{array}$} & \multicolumn{8}{|c|}{ Estimated partial net return $(\$ / \text { plant })^{y}$} \\
\hline & & \multicolumn{8}{|c|}{ Tomato price $(\$ / \mathrm{lb})^{\mathrm{x}}$} \\
\hline & & 1.80 & 2.00 & 2.20 & 2.40 & 2.60 & 2.80 & 3.00 & 3.20 \\
\hline \multicolumn{10}{|c|}{ Nongrafted 'Brandywine'w } \\
\hline-3 & 1.38 & 2.31 & 2.59 & 2.87 & 3.14 & 3.42 & 3.69 & 3.97 & 4.25 \\
\hline-2 & 1.52 & 2.57 & 2.87 & 3.17 & 3.48 & 3.78 & 4.09 & 4.39 & 4.69 \\
\hline-1 & 1.66 & 2.82 & 3.15 & 3.48 & 3.81 & 4.15 & 4.48 & 4.81 & 5.14 \\
\hline Mean & 1.80 & 3.07 & 3.43 & 3.79 & 4.15 & 4.51 & 4.87 & 5.23 & 5.59 \\
\hline+1 & 1.94 & 3.32 & 3.71 & 4.10 & 4.49 & 4.87 & 5.26 & 5.65 & 6.04 \\
\hline+2 & 2.08 & 3.57 & 3.99 & 4.41 & 4.82 & 5.24 & 5.65 & 6.07 & 6.49 \\
\hline+3 & 2.22 & 3.83 & 4.27 & 4.71 & 5.16 & 5.60 & 6.05 & 6.49 & 6.93 \\
\hline \multicolumn{10}{|c|}{ 'Brandywine' grafted onto 'Multifort'v } \\
\hline-3 & 0.90 & 0.84 & 1.02 & 1.20 & 1.38 & 1.56 & 1.74 & 1.92 & 2.10 \\
\hline-2 & 1.04 & 1.09 & 1.30 & 1.51 & 1.72 & 1.92 & 2.13 & 2.34 & 2.55 \\
\hline-1 & 1.17 & 1.33 & 1.56 & 1.79 & 2.03 & 2.26 & 2.50 & 2.73 & 2.96 \\
\hline Mean & 1.31 & 1.58 & 1.84 & 2.10 & 2.36 & 2.63 & 2.89 & 3.15 & 3.41 \\
\hline+1 & 1.45 & 1.83 & 2.12 & 2.41 & 2.70 & 2.99 & 3.28 & 3.57 & 3.86 \\
\hline+2 & 1.59 & 2.08 & 2.40 & 2.72 & 3.04 & 3.35 & 3.67 & 3.99 & 4.31 \\
\hline+3 & 1.73 & 2.33 & 2.68 & 3.03 & 3.37 & 3.72 & 4.06 & 4.41 & 4.76 \\
\hline
\end{tabular}

${ }^{2}$ Yields presented were the estimated mean yield $\pm 3 \mathrm{sE}$, the estimated mean yield was based on pooled data from the 2010 and 2011 organic field trials; $1 \mathrm{lb}=0.4536 \mathrm{~kg}$.

${ }^{{ }}$Matrix values represent [(yield $\left.\times \$ / \mathrm{lb}\right)$ - transplant cost]. Other production, harvest, and packing costs (e.g., land preparation, drip tape, mulch, fertilizer, pest control, labor, etc.) must be factored in to achieve a full net return per plant.

Prices per pound were calculated from published 2008 mo.ly averages for 10-lb cartons of organic heirloom tomato fruit (U.S. Department of Agriculture, 2009); $\$ 1.00 / \mathrm{lb}=\$ 2.2046 / \mathrm{kg}$.

w'Brandywine' is a popular, indeterminate, heirloom, beefsteak tomato cultivar.

"Multifort' is an interspecific hybrid tomato rootstock with resistance to root-knot nematodes and vigorous growth.

Table 4. Estimated partial net return per plant for plants of nongrafted 'Brandywine' tomato and 'Brandywine' grafted onto the rootstock 'Multifort' grown in a transitional organic field with high nematode pressure.

\begin{tabular}{|c|c|c|c|c|c|c|c|c|c|}
\hline \multirow[b]{3}{*}{ SE } & \multirow{3}{*}{$\begin{array}{c}\text { Yield } \\
(\mathrm{lb} / \text { plant })^{\mathrm{z}}\end{array}$} & \multicolumn{8}{|c|}{ Estimated partial net return $(\$ / \text { plant })^{\mathrm{y}}$} \\
\hline & & \multicolumn{8}{|c|}{ Tomato price $(\$ / 1 \mathrm{lb})^{\mathrm{x}}$} \\
\hline & & 1.80 & 2.00 & 2.20 & 2.40 & 2.60 & 2.80 & 3.00 & 3.20 \\
\hline \multicolumn{10}{|c|}{ Nongrafted 'Brandywine'w } \\
\hline-1 & 0.15 & 0.10 & 0.13 & 0.16 & 0.19 & 0.22 & 0.25 & 0.28 & 0.31 \\
\hline Mean & 0.35 & 0.46 & 0.53 & 0.60 & 0.67 & 0.74 & 0.81 & 0.88 & 0.95 \\
\hline+1 & 0.55 & 0.82 & 0.93 & 1.04 & 1.15 & 1.26 & 1.37 & 1.48 & 1.59 \\
\hline+2 & 0.75 & 1.18 & 1.33 & 1.48 & 1.63 & 1.78 & 1.93 & 2.08 & 2.23 \\
\hline+3 & 0.95 & 1.54 & 1.73 & 1.92 & 2.11 & 2.30 & 2.49 & 2.68 & 2.87 \\
\hline \multicolumn{10}{|c|}{ 'Brandywine' grafted onto 'Multifort'v } \\
\hline-3 & 0.84 & 0.73 & 0.90 & 1.07 & 1.24 & 1.40 & 1.57 & 1.74 & 1.91 \\
\hline-2 & 1.04 & 1.09 & 1.30 & 1.51 & 1.72 & 1.92 & 2.13 & 2.34 & 2.55 \\
\hline-1 & 1.24 & 1.45 & 1.70 & 1.95 & 2.20 & 2.44 & 2.69 & 2.94 & 3.19 \\
\hline Mean & 1.44 & 1.81 & 2.10 & 2.39 & 2.68 & 2.96 & 3.25 & 3.54 & 3.83 \\
\hline+1 & 1.64 & 2.17 & 2.50 & 2.83 & 3.16 & 3.48 & 3.81 & 4.14 & 4.47 \\
\hline+2 & 1.84 & 2.53 & 2.90 & 3.27 & 3.64 & 4.00 & 4.37 & 4.74 & 5.11 \\
\hline+3 & 2.04 & 2.89 & 3.30 & 3.71 & 4.12 & 4.52 & 4.93 & 5.34 & 5.75 \\
\hline
\end{tabular}

${ }^{2}$ Yields presented were the estimated mean vield $\pm 3 \mathrm{sE}$, the estimated mean vield was based on pooled data from the 2010 and 2011 organic field trials; $1 \mathrm{lb}=0.4536 \mathrm{~kg}$.

${ }^{y}$ Matrix values represent $[(y i e l d \times \$ / l b)$ - transplant cost $]$. Other production, harvest, and packing costs (e.g., land preparation, drip tape, mulch, fertilizer, pest control, labor, etc.) must be factored in to achieve a full net return per plant.

xrices per pound were calculated from published 2008 mo.ly averages for 10-lb cartons of organic heirloom tomato fruit (U.S. Department of Agriculture, 2009); $\$ 1.00 / \mathrm{lb}=\$ 2.2046 / \mathrm{kg}$.

"'Brandywine' is a popular, indeterminate, heirloom, beefsteak tomato cultivar.

"Multifort' is an interspecific hybrid tomato rootstock with resistance to root-knot nematodes and vigorous growth. between the grafted and nongrafted estimated partial net return in the transitional field. The $\$ 1.81$ expected partial return per plant for $\mathrm{BW} / \mathrm{MU}$ was lower than the $\$ 3.07$ for nongrafted plants under low disease pressure. However, when high levels of RKN infestations occurred, the grafted plants demonstrated great potential for maintaining fruit yield and reducing economic crop losses. O'Connell et al. (2009) reported consecutive crop failures on a farm in North Carolina as a result of soil-borne diseases. In this case, implementation of grafted plants allowed the grower to maintain organic tomato fruit yields and remain profitable where it was previously not possible.

These findings suggest that grafting could be an economically feasible approach to control RKN in heirloom tomato production in organic and transitional organic systems with severe RKN pressure. Grafting could be critical for growers in the transition process from conventional to organic farming systems with high populations of soil-borne pathogens and nematodes. Many of the pest control strategies employed in organic or alternative cropping systems can take multiple seasons to have a beneficial effect (McSorley, 2002), whereas grafting effects are immediate. Resistant rootstocks can also reduce field infestation levels for subsequent crops and provide a nonhost root system in a crop rotation. Grafting may also reduce the need for expensive fumigants in conventional farming systems thereby reducing input costs. Although this study focused on the use of grafting to control tomato RKN, grafting has been used successfully in the United States for managing bacterial wilt (caused by Ralstonia solanacearum), Fusarium wilt (Rivard and Louws, 2008), as well as southern blight (caused by Sclerotium rolfsii) in tomato production (Rivard et al., 2010a).

\section{Conclusions}

As the demand for organically produced fruits and vegetables continues to rise, more organic farmers will need effective soil-borne disease control methods. Grafting is an effective tool for soil-borne disease management that carries economic considerations with it. A grower must understand the benefits and limitations associated with grafting. Our findings suggest the use 
of grafted plants may be appropriate in fields with a history of high soilborne disease pressure. Actual production costs for individual farmers will vary and for that reason only transplant costs were included in our cost-benefit analyses.

This study was designed to provide a base line reference for growers interested in producing and using grafted transplants on-farm. Further work should examine local production methods and costs to provide accurate information for growers in diverse environments. More rootstocks should be developed for open-field production, which in Florida is typically associated with short, wet, and hot seasons. The vigorous rootstocks that are adapted to the greenhouse conditions may not be suitable for field production. Early harvests may be more important to open-field tomato growers to capture highest market prices.

It is expected that more growers in the United States may consider using grafted transplants for soil-borne disease control in the near future (King et al., 2008; Kubota, 2008; Lee et al., 2010). Researchers, extension agents, and growers will need to work together to ensure that rootstocks suited for open-field conditions and the appropriate scion-rootstock combinations are used to optimize the benefits of this technique. The economic viability of grafted vegetable production will ultimately depend on farmers to identify the soil-borne disease problem at their production site and choose the suitable rootstock and scion to meet their needs.

\section{Literature cited}

Bausher, M.G. 2009. Commercial tomato rootstock performance when exposed to natural populations of root-knot nematodes in Florida. HortScience 44:1021 (abstr.).

Florida Department of Economic Opportunity. 2011. Occupational Employment Statistics and Wages, 2011 Wage Estimates. 9 Dec. 2011. <http://www.floridajobs.org/ labor-market-information/data-center/ statistical-programs/occupationalemployment-statistics-and-wages $>$.

Greene, C., C. Dimitri, B.H. Lin, W. McBride, L. Oberholtzer, and T. Smith. 2009. Emerging issues in the U.S. organic industry. EIB-55, U.S. Dept. Agr. Econ. Res. Serv., Washington, DC.

King, S.R., A.R. Davis, W. Liu, and A. Levi. 2008. Grafting for disease resistance. HortScience 43:1673-1676.

Kline, W. and P. Nitzsche. 2005. Heirloom tomato cultivar evaluation for the New Jersey market. HortScience 40: 1031 (abstr.).

Kubota, C. 2008. Use of grafted seedlings for vegetable production in North America. Acta Hort. 770:21-28.

Kubota, C., M.A. McClure, N. KokalisBurelle, M.G. Bausher, and E.N. Rosskopf. 2008. Vegetable grafting: History, use, and current technology status in North America. HortScience 43:1664-1669.

Lee, J.M., C. Kubota, S.J. Tsao, Z. Bie, P. Hoyos Echevarria, L. Morra, and M. Oda. 2010. Current status of vegetable grafting: Diffusion, grafting techniques, automation. Sci. Hort. 127:93-105.

López-Pérez, J.A., M. Le Strange, I. Kaloshian, and A.T. Ploeg. 2006. Differential response of $\mathrm{Mi}$ gene-resistant tomato rootstocks to root-knot nematodes (Meloidogyne incognita). Crop Protection 25:382-388.

Louws, F.J., C.L. Rivard, and C. Kubota. 2010. Grafting fruiting vegetables to manage soilborne pathogens, foliar pathogens, arthropods and weeds. Sci. Hort. 127:127-146.

McSorley, R. 2002. Nematode and insect management in transitional agricultural systems. HortTechnology 12:597-600.

O'Connell, S., S. Hartmann, C. Rivard, M. Peet, and F. Louws. 2009. Grafting tomatoes on disease resistant rootstocks for small-scale organic production. $9 \mathrm{Dec}$. 2011. <http://ofrf.org/funded/highlights/oconnell_07f30.html>.

Rivard, C. and F. Louws. 2006. Grafting for disease resistance in heirloom tomatoes. North Carolina Coop. Ext. Serv. Bul. Ag-675.

Rivard, C.L. and F.J. Louws. 2008. Grafting to manage soilborne diseases in heir- loom tomato production. HortScience 43:2104-2111.

Rivard, C.L., S. O'Connell, M.M. Peet, and F.J. Louws. 2010a. Grafting tomato with interspecific rootstock to manage diseases caused by Sclerotium rolfsii and southern root-knot nematode. Plant Dis. 94:1015-1021.

Rivard, C.L., O. Sydorovych, S. O'Connell, M.M. Peet, and F.J. Louws. 2010b. An economic analysis of two grafted tomato transplant production systems in the United States. Hort Technology 20:794-803.

Roberts, P.A., W.C. Matthews, Jr., and J.D. Ehlers. 2005. Root-knot nematode resistant cowpea cover crops in tomato production systems. Agron. J. 97:16261635 .

Taylor, M., B. Bruton, W. Fish, and W. Roberts. 2008. Cost benefit analysis of using grafted watermelon transplants for Fusarium wilt disease control. Acta Hort. 782:343-350.

U.S. Department of Agriculture. 2002. Code of Federal Regulations, Title 7, Part 205. National Organic Program. 9 Dec. 2011 . <http://www.ams. usda.gov/AMSvl $.0 /$ getfile? dDocName= STELDEV3004452>.

U.S. Department of Agriculture. 2009. Wholesale vegetable prices, Boston and San Francisco, 2008. 9 Dec. 2011. <http:// www.ers.usda.gov/Data/OrganicPrices/>.

Venema, J.H., B.E. Dijk, J.M. Bax, P.R. van Hasselt, and J.T.M. Elzenga. 2008. Grafting tomato (Solanum lycopersicum) onto the rootstock of a high-altitude accession of Solanum habrochaites improves suboptimal-temperature tolerance. Environ. Exp. Bot. 63:359-367.

Verdejo-Lucas, S. and F.J. Sorribas. 2008. Resistance response of the tomato rootstock SC 6301 to Meloidogyne javanica in a plastic house. Eur. J. Plant Pathol. 121:103-107.

Williams, D.R., C.R. Andersen, S.E. Eaton, and L.W. Martin 2005. Tomato cultivar evaluation in Arkansas. HortScience 40:890 (abstr.).

Zeck, W.M. 1971. A rating scheme for field evaluation of root-knot nematode infestations. Pflanzenschutz-Nachrichten Bayer 24:141-144. 